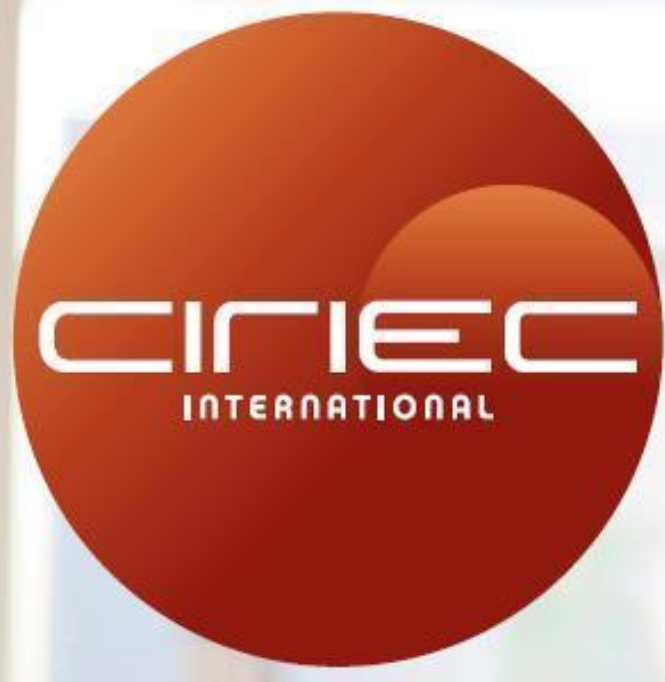

Working Paper

Biomed Europa: after the coronavirus, a public infrastructure to overcome the pharmaceutical oligopoly

Massimo FLORIO

CIRIEC No. 2020/08 
CIRIEC activities, publications and researches are realised with the support of

Les activités, publications et recherches du CIRIEC sont réalisées avec le soutien de
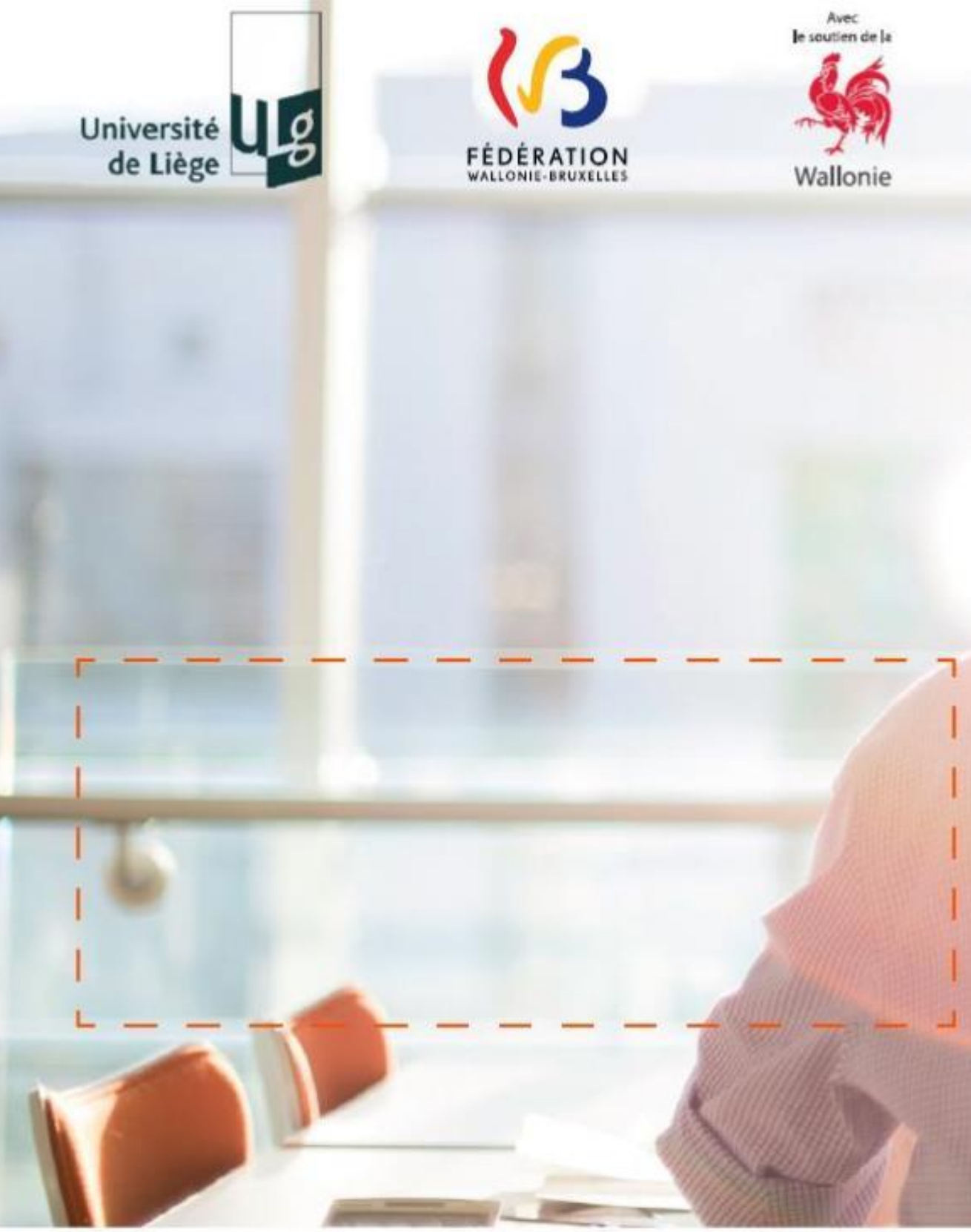


\title{
Biomed Europa: after the coronavirus, a public infrastructure to overcome the pharmaceutical oligopoly ${ }^{*}$
}

\author{
Massimo Florio ${ }^{1}$
}

Working paper CIRIEC No. 2020/08

\footnotetext{
* This note draws from the intervention (in Italian) at the streamed event "Inequality in times of crisis. A year in our lives that has been more useful than ever before: our 15 proposals" $\left(25^{\text {th }}\right.$ March 2020) Inequality and Diversity Forum, https://www.forumdisuguaglianzediversita.org, and the Webinar, Società Italiana degli Economisti, June 4, 2020. I am grateful for comments on an earlier version to Laura lacovone and Letizia Giorgetti, University of Milan; Marta Florio, Harvard Medical School; Jérôme Schoenmaeckers and Barbara Sak, CIRIEC International.

${ }^{1}$ University of Milan, Department of Economics, Management, Quantitative Methods (Via Conservatorio 7, 20122 Milano - Italy; Email: massimo.florio@unimi.it; www.massimoflorio.com).
} 


\section{Abstract}

As of June $30^{\text {th }}, 2020$, the global outbreak of Severe Acute Respiratory Syndrome (SARS)-associated coronavirus 2 (SARS-CoV-2) has claimed about 500,000 lives, with over 10 million confirmed cases and nearly 3 billion people around the world under some form of lockdown. The COVID-19 pandemic has exposed profound weaknesses in a global health system that in the last decades relied in most countries too heavily on the pro-profit private sector for the discovery, development and distribution of new drugs. Pharmaceutical research is slow, risky, and costly. Governments allocate public funds to health-related research - grants for the most part aimed at supporting research upstream of drug development. Rather, late-stage drug development is largely funded by private pharmaceutical companies, drug corporations and venture capitals, which are incentivized to invest by a system of patent monopolies. To maximize their financial returns, private agents invest almost exclusively on the most marketable and profitable biomedical sectors, where drugs command the highest profits even if sometimes offer marginal therapeutic improvements and have little impact on social welfare. Critically important biomedical research sectors remain thus underfunded, and urgent public health needs are left unmet by the investment plans of the industry. Such was the case of drug development to prevent and fight coronavirus infections - neglected by "Big-Pharma" companies despite the alarming concerns raised by the scientific community for almost 20 years, the predicted economic burden of a pandemic on the public sanitary system, and the undisputable societal benefits represented by the discovery of an affordable cure. This pandemic provides a fundamental lesson - one ignored after the outbreak of SARS in 2003, the epidemic of MERS in 2006, and other past pandemics - a lesson about infectious threats that we face globally and that exacerbate vulnerabilities associated with income inequality and health disparities. It is now imperative to rethink the present public health funding strategy, and the roles and goals of all players involved. Here, after a brief analysis of the causes underlying the failure of the private sector to prevent and address the present COVID-19 pandemic, we propose a structural intervention aimed at creating the conditions for a new model of public health research. We detail a plan for an international, interconnected, transparent, science-informed, and publicly funded research infrastructure for pharmaceutical and biomedical research - BIOMED EUROPA. The proposed platform aims at identifying research priorities in the public health sector, 
focusing efforts on the development of preventive and therapeutic strategies against those diseases that pose the greatest threats to human and social welfare. We suggest that BIOMED EUROPA should be managed as both a research infrastructure, along the model of CERN (the European Organization for Nuclear Research, Geneva) or the EMBL (European Molecular Biology Laboratory, Heidelberg) and as a knowledge-intensive public enterprise with an industrial policy mission, such as the ESA (European Space Agency).

Keywords: pharmaceutical industry; biomedical research; Covid-19; public research infrastructure

JEL Codes: H51, I11, L32, O32 


\title{
1. The coronavirus as a market failure in the pharmaceutical industry
}

The current pandemic shows a spectacular failure over the last twenty years in research about infectious diseases on the part of the pharmaceutical industry. At the same time, it points to a policy failure of the governments that mostly entrusted our defence against infectious diseases to pharma companies. In this note I briefly ask three questions: Was the current pandemic unpredictable? Why were we so unprepared to deal with it? What can be done to avoid in future to face a similar emergency?

The pandemic was not just predictable, it was actually predicted by scientists. First, there was SARS-CoV-1 (Severe Acute Respiratory Syndrome), a serious epidemic caused by a strain of coronavirus in 2002. Then MERS (Middle East Respiratory Syndrome), another epidemic caused by a strain of coronavirus in 2012. In 2015 laboratory experiments showed how the coronavirus hosted by certain species of bats could prove dangerous to man (Menachery et al., 2015).

In 2012, the famous scientific journalist David Quammen, author of "Spillover", after having interviewed dozens of experts, wrote:

\begin{abstract}
"I asked [...] two precise questions: 1 ) in the near future will a disease emerge that is virulent and infectious enough to cause a pandemic on the same scale as AIDS or Spanish Flu, with tens of millions of deaths? 2) and if so, what form will it take and where will it come from? The replies to the first question varied from "Perhaps" to "Probable". While for the second, the majority leaned towards an RNA virus [...]" (Quammen, 2012).
\end{abstract}

Coronaviruses are RNA viruses, with a relatively simple structure that mutate frequently due to the lack of mechanisms to correct the replication 'errors', correction mechanisms that are typical of DNA. This variability over time, together with the fact that replication necessarily occurs inside the cells of the infected person, makes it difficult to find a vaccine that does not have serious side-effects. However, it is also an established fact that for almost 18 years prior to the Covid 19 outbreak, the pharmaceutical industry had made very limited R\&D investments in this direction, with only six clinical recorded by the WHO in 2019 (before the outbreak) for any type of coronavirus, in spite of considerable NIH and other public funders' grants (Mazzucato and Momenghalibaf, 2020).

In fact, the pharmaceutical industry deemed that research on a vaccine was a pointless investment, despite the opinions of authoritative experts such as Peter Hotez, Baylor College of Medicine (Altman 2020). He 
recently (March 5,2020$)$ testified before the US Congress that during the first SARS epidemic in 2003 his team developed a vaccine but was unable to secure enough funding to begin clinical trials ${ }^{2}$.

Today we regret having abandoned these tests because they would have provided a starting point, as Jason Schwartz of the Yale School of Public Health said recently: "Had we not set aside the SARS vaccine research programme, we would have had a lot more foundational work that we could apply to this new, closely related virus" (Buranyi, 2020). This was admitted even by the OECD General Secretary, Angel Gurrìa, in a letter to the G20: "Had a vaccine for the SARS-CoV-1 been developed at the time, it would have accelerated the development of one for the current outbreak given that the two viruses are $80 \%$ similar"3.

Neither did the industry develop any research into antiviral drugs that may prevent the progress of this type of disease after infection. This was not beyond their reach. According to Prof. Haseltine of Harvard Medical School, all coronaviruses have a common molecular structure and once the various types of genome have been sequenced, drugs that block the enzymes necessary for their growth are feasible and should be developed, produced and accumulated in anticipation of the next pandemic ${ }^{4}$. Yes, but by whom?

\section{Why the pharmaceutical industry wasn't interested}

Research into infectious diseases is not a priority for pharmaceutical companies. In 2019, as mentioned, there were a total of just six clinical trials and ten basic and pre-clinical studies on all types of coronaviruses, and no drugs were being registered on the part of the industry (Rizvi, 2020), despite substantial public subsidies (amounting to an estimated total of US\$ 700 million since the first SARS outbreak). In 2019 the Top 20 Pharma companies were busy carrying out research into about 400 new drugs, half of them anticancer drugs (which currently sell for an average of US\$195,000 per treatment) but only 65 projects into any type of infectious disease. Before the outbreak only very few of the Big Pharma firms had a stable research unit for vaccines. It appears that some of the Big Pharma are even no longer

\footnotetext{
${ }^{2}$ https://unfoundation.org/blog/post/qa-with-dr-peter-hotez-behind-the-scenes-of-covid19-vaccine-research/

${ }^{3}$ https://www.oecd.org/about/secretary-general/Coronavirus-COVID-19-Joint-actions-towin-the-war.pdf

${ }^{4}$ https://www.uschinahealthsummit.org/single-post/2020/02/21/What-Needs-to-be-Doneto-Deal-with-COVID-19-in-China-An-Interview-with-William-Haseltine
} 
researching new antibiotics (Rizvi, 2020) despite the expectation that by around 2050 bacteria that are resistant to current drugs could kill 10 million people a year (O'Neill, 2016).

The business model of the pharmaceutical industry focusses primarily on 'blockbuster' drugs that bring in billions of dollars in annual turnover (Rea et al., 2018). The typical target markets for these drugs are chronic pathologies, such as high cholesterol, diabetes and hypertension. A cholesterol-combatting drug like Lipitor alone generated US\$ 150 billion for Pfizer in less than 20 years. Certain types of cancer require long-term therapies that ensure high and lasting profits.

Rea et al. (2018) provide numerous examples of how explorative drug research - with its related risks - is almost always initially carried out by teams in universities and small start-ups, often with critically public funding. The Big Pharma companies only enter the arena when the investment appears promising in terms of a geographically broad market that is expected to increase over time (Chakravarthy et al., 2015; Prasad \& Mailankody, 2017). Priority is not given to infectious diseases that give rise to local epidemics, often in areas with low spending power (as Ebola in Africa), or those that once infection has been eradicated do not guarantee an interesting market that is commensurate with the risks of research into moving targets.

A pandemic like the present one would potentially offer a global market, with potential sales in the region of billion dollars for a vaccine (Gard, 2020) or drugs, but due to its nature, it does not result in a chronic condition: people recover and become immune or they die within a relatively short period of time. It is not a stable market to invest in, unless governments offer pharmaceutical firms substantial subsidies to encourage them to do research (T'Hoen, 2020). The USA government is doing this after the novel coronavirus outbreak, with over a billion dollars destined to the National Institutes of Health (which are part of the Department of Health and Human Services) and to other agencies, which in turn will ultimately turn it over to the pharmaceutical sector, usually with the mediation of university teams.

Thanks to their unrivalled lobbying activities, the pharma companies managed to get the US Congress to reject an amendment by the Democrats to the over US\$2,000 billion recovery bill, which has been approved on March 29, 2020, to tackle the economic and social crisis provoked by coronavirus. The amendment aimed to control the prices of any vaccines or drugs obtained by private research institutes using public funds. Not only was the amendment rejected, but a ruling was introduced that explicitly forbids the government from limiting 
the prices demanded by the pharmaceutical firms that patent the COVID-19 drugs (Mazzucato and Momenghalibaf, 2020).

\section{The system is sick: we must abandon it}

The biomedical research system is suffering from a distortion in its mission, from an irreconcilable contradiction between the priorities of science for health and science for profit, that appears in the form of extra- profits (see GAO, 2017). This illness can be cured by a radical research policy change: a large public infrastructure that is involved throughout the whole drug life cycle: research, development, production and distribution. Not just another regulatory agency, but a knowledge-intensive public enterprise (Castelnovo and Florio, 2020; Bernier et al., 2020). A place like the CERN in Geneva, that serves both as a physical hub for thousands of resident researchers and as a virtual hub for tens of thousands of scientists and medical doctors in global partnerships. Also like the European Space Agency, an intergovernmental body with an industrial policy mission. The body managing the biomed infrastructure should decide on its own priorities according to the recommendations of the scientific community and of the public health systems part of the project. This body should reserve the right to the intellectual property of the discoveries, in the public interest only, with the right to produce directly or through licensed third parties, drugs, vaccines and biomed technologies at affordable prices to share the benefits of knowledge with the world. Price affordability, in a comprehensive concept, also depends on the reimbursement mechanism within the social security systems (notably in Europe), collective purchases of drugs, fixed maximum prices in certain countries, "admissible" drugs for reimbursement versus other that are not, etc.

A new pharmaceutical R\&D policy was proposed for the USA by the Democracy Collaborative think tank (Brown, 2019). It contemplates a) a drug research and development institute, at federal level, that is involved throughout the cycle of pharmacological research (including clinical trials), possibly to be located at the previously mentioned National Institutes of Health in the Maryland campus; b) a number of public manufacturing firms at regional, state or municipal level to produce these new drugs or generics for sale at low prices; c) wholesale distributors that are also public, like the public postal service; d) private retail pharmacies and hospitals could then rely on a constant supply at accessible prices, with speedy delivery; e) patients can finally access therapies and escape from the monopolistic market conditions that prevail today and that they end up paying for, either directly or indirectly. 


\section{BIOMED EUROPA. The proposal}

How much would a European version of this kind of project cost? In the USA, the $\mathrm{NIH}$ has an annual budget of US\$ 41.68 billion (fiscal year 2020) over 80 percent of which is redistributed in the form of non-repayable loans to third parties, including universities, research hospitals, other institutes and pharmaceutical firms ("In general, domestic or foreign, public or private, nonprofit or for-profit organizations are eligible to receive NIH grants", see https://grants.nih.gov/grants/who-is-eligible.htm).

Ultimately, the results of a large share of this research would be incorporated into the development, production and sale of the products by the pharmaceutical industry. Although the scientific results of such generous public funding are often excellent, there is a built-in inefficiency in this mechanism. Subsidising ultimately the R\&D budgets of pharma companies with public funds perpetuates a distortion of research priorities that is at the root of the failure with the novel coronavirus and other pathologies. The priorities of pharma companies are not aligned with public health priorities. Decades of subsidies and protection of intellectual property of discoveries through patents had not cured this issue. The traditional Schumpeterian argument that monopoly spurs innovation (see for example Mc Kenzie and Lee, 2008) may or may not be true in certain industries, but in the pharma industry, it leads to a clear failure of markets to address the global externalities arising from infectious diseases. Both suppliers of R\&D, and eventually of vaccines and drugs, on one side, and potential patients, on the other side, are unable to internalize the huge social cost and benefits related to a possible pandemic. In fact, more generally, companies and patients are both unable to appraise, not even approximately, the net expected social benefits of prevention and cure of a large class of pathologies, because of incomplete information and lack of individual incentives to counteract potential risks. This is the main rationale for public intervention in a new form.

The project that I would call BIOMED EUROPA, should have an annual budget on the same scale of that of the NIH, for example, 15-20 billion Euro, about 0.10 of GDP of the EU (by comparison: the European Commission proposal for the EU budget 2021-2027 for the Common Agricultural Policy is Euro 365 billion, https://ec.europa.eu/commission/news/eu-budget-commonagricultural-policy-after-2020-2018-jun-01 en). Moreover, as with ESA, or CERN, member states do not need to be EU members.

A European dimension at least is essential for two reasons: the resources to be deployed are greater than those that any single state can afford, even the 
larger ones; experimentation through multicentre clinical trials, and subsequently the production and distribution of the drugs, requires an infrastructure on an international scale. Data collection (including certain Big Data) needs to go beyond national borders to maximize the effectiveness of therapies. The project could aspire to be the largest public biomedical research infrastructure in the world and, at the same time, the largest enterprise in the sector, competing transparently with the Big Pharma (or perhaps also convincing them to collaborate on equitable terms when appropriate). BIOMED EUROPA could be based on an inter-governmental treaty that gives rise to a supranational institution, with its headquarters adjoining, for example, the European Molecular Biology Laboratory (EMBL) in Heidelberg ${ }^{5}$, which is already a supranational structure, or on the future Human Technopole campus $^{6}$, or at any of the excellent but too fragmented research infrastructures that already exist in Europe (Florio, 2019). It might be critically important to devise a system of conventions with the national health systems for the development of clinical trials; but also to organise, in collaboration with some industrial partners, owned or rented industrial plants for manufacturing the drugs. It could build a logistics distribution network through the national public postal systems or through tenders open to private firms.

Over time, BIOMED EUROPA could build its own large portfolio of drugs, vaccines, equipment, software focussing on everything that the private sector does not do or that it does at exorbitant prices, thus overcoming the existing Big Pharma oligopoly, without having to resort to full nationalisation (which occasionally has been proposed) ${ }^{7}$. In addition, as proposed by Brown (2020) for the USA, BIOMED EUROPA could build up a portfolio of generic drugs which, produced to very high quality certified standards, could substitute the drugs that persist on the market despite the existence of sometimes valid and sometimes uncertain alternatives.

\section{Feasibility}

I am convinced that this project is feasible from both the scientific and the technological points of view, and that it is financially sustainable through three complementary mechanisms, in proportions yet to be studied:

\footnotetext{
${ }^{5}$ https://www.embl.de

${ }^{6}$ https://www.humantechnopole.it

${ }^{7}$ https://www.pharmaceutical-journal.com/news-andanalysis/opinion/correspondence/drug-industry-should-be-nationalised-and-kept-undercontrol/10004829.article, see also https://www.bmj.com/content/368/bmj.m769
} 
a) a base of transfers from the budgets of member states (based on the CERN or European Space Agency models), channelling into BIOMED EUROPA the numerous inadequate streams of national public funds supporting research, currently captured directly or indirectly by private firms, at times with the mediation of the universities, which in turn often end up attracted by the "business" logic;

b) a market component of revenues deriving from production licences and from the distribution at cost of the new drugs (and biomedical technologies in general) to national health systems and a well-built portfolio of certified high quality generic drugs;

c) lastly, with an agreement at EU level, through the levy of a special purpose tax, on a ten-year basis for example, on the sales of private pharmaceutical firms in Europe, or other mechanisms. Official sources like the General Accounting Office of the USA estimate that today the profitability of pharmaceutical firms is often double that of the top 500 companies worldwide. The time has come to recuperate a public dividend to invest in research.

But as a social benefit the greatest return of BIOMED EUROPA would come from the lower economic impact of severe pathologies, better quality of life, greater security and social cohesion. The business model of the pharmaceutical industry is not compatible with the challenges of today or tomorrow. What is it costing us to have been caught by surprise, totally unprepared for the new coronavirus, despite predictions that there was a high probability of a pandemic? It is possible that having arrived helpless at our foreseeable appointment with this single pandemic will have a social cost equal to a global recession of several percentage points of GDP already in 2020, a multiple of the one tenth of a percent point of GDP that I propose to fund the public biomedical research infrastructure. Not to mention the suffering for many people that could be avoided or limited by a biomedical research model that is oriented towards needs, scientific excellence and to planning the response to emergencies. It would be worthwhile working on a feasibility study for such a project, to be integrated with a collective European management of health emergency systems.

Today we ask ourselves how it could have happened that apparently advanced economies woke up not only without vaccines and drugs, but also without ventilators or even face masks. It must never happen again. 


\section{Bibliography}

ALTMAN, M.J, (2020), "Q\&A with Dr. Peter Hotez: Behind the scenes of Covid-19 vaccine research", United Nations Foundation, 15 May,

https://unfoundation.org/blog/post/qa-with-dr-peter-hotez-behind-the-scenes-ofcovid-19-vaccine-research/

BERNIER, L., FLORIO, M., \& BANCE, P. (2020), The Routledge Handbook of StateOwned Enterprises, Routledge.

BROWN, D. (2019), "Medicine for all. The case for a public option in the pharmaceutical industry", Democracy Collaborative, 31 August,

https://democracycollaborative.org/learn/publication/medicine-all-case-publicoption-pharmaceutical-industry

BURANYI, S. (2020), "How profit makes the fight for a coronavirus vaccine harder", The Guardian, 4 March,

https://www.theguardian.com/commentisfree/2020/mar/04/marketcoronavirus-vaccine-us-health-virus-pharmaceutical-business

CASTELNOVO, P. and FLORIO, M. (2020), "Mission-oriented public organizations for knowledge creation" in Bernier L, Florio M, Bance P (eds.), The Routledge Handbook of State-Owned Enterprises, Routledge.

CHAKRAVARTHY, R., COTTER, K., DiMASI, J., MILNE, C.P., \& WENDEL, N. (2015), "Public and Private Sector Contributions to the Research \& Development of the Most Transformational Drugs of the Last 25 Years: From Theory to Therapy", Therapeutic Innovation \& Regulatory Science, 50(6), 759-768, https://doi.org/10.1177/2168479016648730

CLEARY, et al. (2018), "Contribution of NIH funding to new drug approvals 20102016", Proceedings of the National Academy of Sciences, 115(10), 2329-2334, https://doi.org/10.1073/pnas.1715368115

FLORIO, M. (2019), Investing in Science. Social Cost-Benefit Analysis of Research Infrastructures, The MIT Press.

GAO (2017), "Drug Industry: Profits, Research and Development Spending, and Merger and Acquisition Deals", GAO, https://www.gao.gov/products/GAO-18-40\#summary

GARD, D. (2020), "An updated guide to the coronavirus drugs and vaccines in development", STAT, 19 ${ }^{\text {th }}$ March, https://www.statnews.com

GURRìA, A. (2020), Coronavirus (COVID-19): Joint actions to win the war, OECD, https://www.oecd.org/about/secretary-general/Coronavirus-COVID-19-Jointactions-to-win-the-war.pdf 
MA, J. (2020), "What Needs to be Done to Deal with COVID-19 in China: An Interview with William Haseltine", $21^{\text {st }}$ February, US-China Health Summit, https://www.uschinahealthsummit.org/single-post/2020/02/21/What-Needs-tobe-Done-to-Deal-with-COVID-19-in-China-An-Interview-with-William-Haseltine

MAZZUCATO, M. and MOMENGHALIBAF, A. (2020), "Drug companies will make a killing from coronavirus", New York Times, $18^{\text {th }}$ March, https://www.nytimes.com/2020/03/18/opinion/coronavirus-vaccine-cost.html

Mc KENZIE, R.B. and LEE, D.R. (2008), In Defense of Monopoly, How Market Power foster Creative Knowledge, The University of Michigan Press.

MENACHERY, V., YOUNT, B., DEBBINK, K., et al. (2015), "A SARS-like cluster of circulating bat coronaviruses shows potential for human emergence", Nature Medicine, 21, 1508-1513, https://doi.org/10.1038/nm.3985

O’NEILL, J. (2016), “Tackling Drug-Resistant Infections Globally: Final Report and Recommendations", May, Review on Antimicrobial Resistance, https://tinyurl.com/la9b5cb

PRASAD, V., \& MAILANKODY, S. (2017), "Research and development spending to bring a single cancer drug to market and revenues after approval", JAMA internal medicine, 177(11), 1569-1575, http://doi.org/10.1001/jamainternmed.2017.3601

QUAMMEN, D. (2017), Spillover. L'evoluzione delle pandemie, $12^{\text {th }}$ edition, trans. L. CIVALLERI, Adelphi.

REA, P.A., PAULY, M.V., BURNS, L.R. (2018), Managing discovery in the life sciences. Harnessing creativity to drive the biomedical innovation, Cambridge University Press.

RIZVI, Z. (2020), "How the COVID-19 outbreak shows the limits of pharma's monopoly model", PublicCitizen, $20^{\text {th }}$ February, https://citizen.org

T'HOEN, H. (2020), "Coronavirus. The latest problem Big Pharma won't solve", Barron's, $7^{\text {th }}$ February, https://www.barrons.com/articles/coronavirus-the-latestproblem-big-pharma-wont-solve-51581078600 
This yearly series of working papers (WP) aims to publish works resulting from the scientific network of CIRIEC. The WPs are subject to a review process and are published under the responsibility of the President of the International Scientific Council, the president of the scientific Commissions or the working groups coordinators and of the editor of CIRIEC's international scientific journal, the Annals of Public and Cooperative Economics.

These contributions may be published afterwards in a scientific journal or book.

The contents of the working papers do not involve CIRIEC's responsibility but solely the author(s') one.

The submissions are to be sent to CIRIEC (iriec@uliege.be).

Cette collection annuelle de Working Papers (WP) est destinée à accueillir des travaux issus du réseau scientifique du CIRIEC. Les WP font l'objet d'une procédure d'évaluation et sont publiés sous la responsabilité du président du Conseil scientifique international, des présidents des Commissions scientifiques ou des coordinateurs des groupes de travail et du rédacteur de la revue scientifique internationale du CIRIEC, les Annales de l'économie publique, sociale et coopérative.

Ces contributions peuvent faire l'objet d'une publication scientifique ultérieure.

Le contenu des WP n'engage en rien la responsabilité du CIRIEC mais uniquement celle du ou des auteurs.

Les soumissions sont à envoyer au CIRIEC (ciriec@uliege.be).

This working paper is indexed and available in RePEc

Ce working paper est indexé et disponible dans RePEc

ISSN 2070-8289

ISBN 978-2-931051-38-2

EAN 9782931051382

http://doi.org/10.25518/ciriec.wp202008

D/2020/1406/8-d 


\section{WP Collection 2020}

2020/01 Building Sustainable Local Food Solutions: How Canadian Indigenous Communities are Using the Social and Solidarity Economy to Implement Zero Hunger

Jennifer SUMNER, M. Derya TARHAN \& John Justin McMURTRY

2020/02 L'Economie solidaire en Turquie et son écosystème: un avenir encore incertain

Olivier GAJAC \& Selin PELEK

2020/03 Le recouvrement des coûts : un défi pour une gestion durable des déchets ménagers en Algérie. Cas de la Commune d'Annaba Tahar TOLBA, Aurore MORONCINI \& Youcef KEHILA

2020/04 Agricultural production cooperatives and agricultural development: Is there a niche after all? Findings from an exploratory survey in China Axel WOLZ, Shemei ZHANG \& Ya DING

2020/05 Long Way to Universal Health Coverage (UHC): Are Policy Dialogue Processes Appropriate to Negotiate Trade-Offs in Africa? The Cases of Benin and Senegal

Elisabeth PAUL, Fabienne FECHER, Céline DEVILLE, Youssoupha NDIAYE, Farba Lamine SALL, N'koué Emmanuel SAMBIÉNI, Remo MELONI \& Denis PORIGNON

2020/06 In the Quest for Semi-Industrialized Economy: Strategies for AgriculturalBased Industrialization through Co-operatives in Tanzania Paulo ANANIA \& Paschal NADE

2020/07 La gouvernance des entreprises publiques en situation de monopole Pierre BAUBY

2020/08 Biomed Europa: after the coronavirus, a public infrastructure to overcome the pharmaceutical oligopoly Massimo FLORIO 


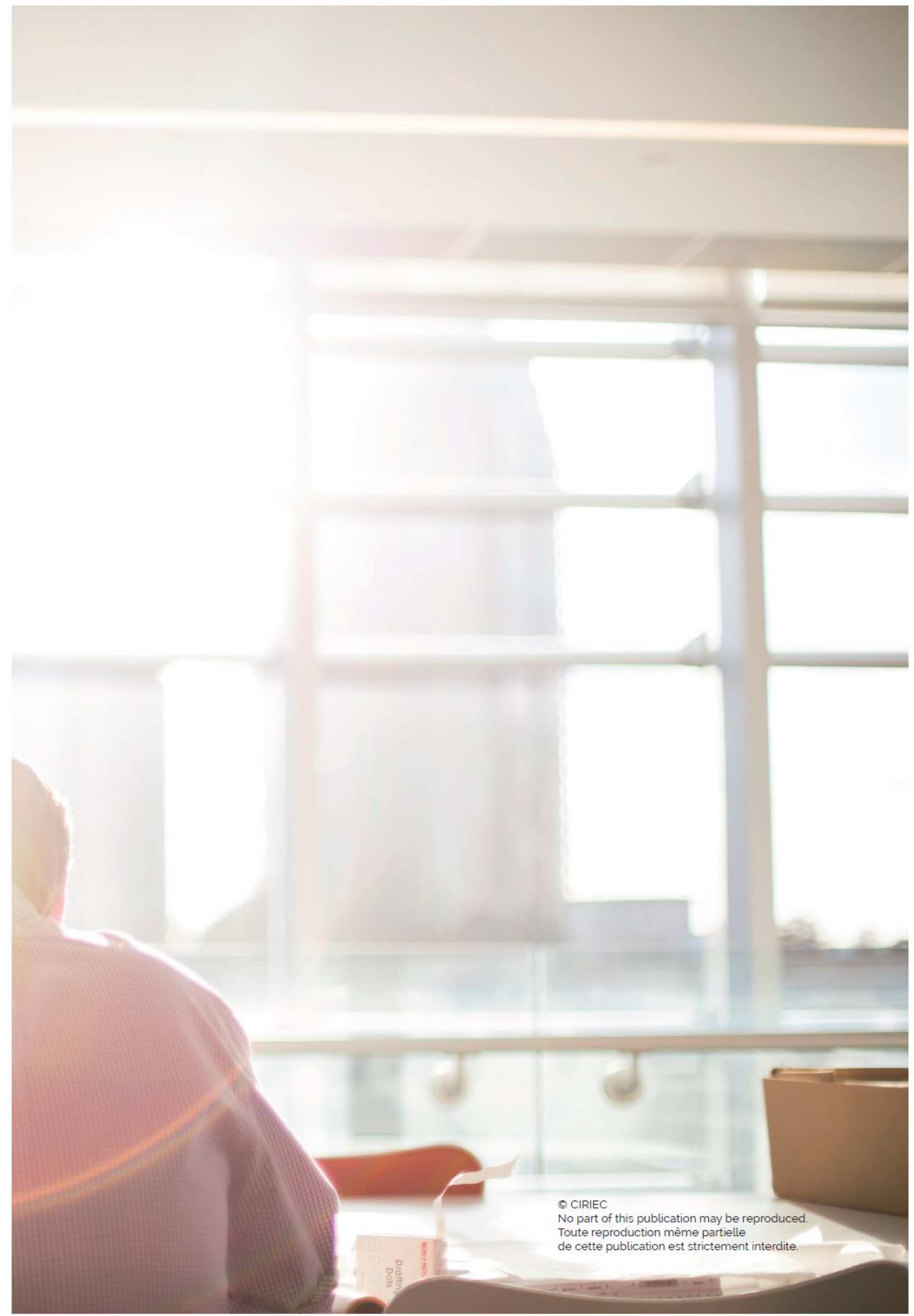


CIRIEC (International Centre of Research and Information on the Public, Social and Cooperative Economy) is a non-governmental international scientific organization.

Its objectives are to undertake and promote the collection of information, scientific research, and the publication of works on economic sectors and activities oriented towards the service of the general and collective interest: action by the State and the local and regional public authorities in economic fields (economic policy, regulation); public utilities; public and mixed enterprises at the national, regional and municipal levels; the so-called "social economy" (not-for-profit economy, cooperatives, mutuals, and non-profit organizations; etc.).

In these fields CIRIEC seeks to offer information and opportunities for mutual enrichment to practitioners and academics and for promoting international action. It develops activities of interest for both managers and researchers.

Le CIRIEC (Centre International de Recherches et d'Information sur l'Economie Publique, Sociale et Coopérative) est une organisation scientifique internationale non gouvernementale.

Ses objectifs sont d'assurer et de promouvoir la collecte d'informations, la recherche scientifique et la publication de travaux concernant les secteurs économiques et les activités orientés vers le service de l'intérêt général et collectif : l'action de l'Etat et des pouvoirs publics régionaux et locaux dans les domaines économiques (politique économique. régulation) : les services publics : les entreprises publiques et mixtes aux niveaux national, régional et local: « l'économie sociale » : coopératives, mutuelles et associations sans but lucratif : etc.

Le CIRIEC a pour but de mettre à la disposition des praticiens et des scientifiques des informations concernant ces différents domaines, de leur fournir des occasions d'enrichissement mutuel et de promouvoir une action et une réflexion internationales. Il développe des activités qui intéressent tant les gestionnaires que les chercheurs scientifiques.

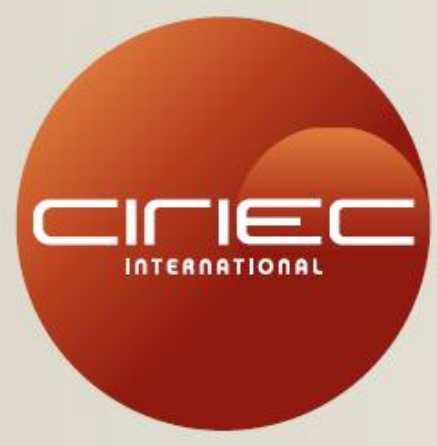

INTERNATIONAL CENTRE OF RESEARCH AND INFORMATION ON THE PUBLIC, SOCIAL AND COOPERATIVE ECONOMY-AISBL

CENTRE INTERNATIONAL DE RECHERCHES ET D'INFORMATION SUR L'ÉCONOMIE PUBLIQUE, SOCIALE ET COOPÉRATIVE - AISBL

Universite de Liège | Quartier Agora | Place des Orateurs 1 | Bātiment B33 boite 6 | BE-4000 Liege (Belgium) | T+32(0)436627 46 | F+32(0)43662958 ciriec@ulg.ac.be | www.cirieculg.ac.be 